\title{
Effects of Dietary Phospholipids on Lipid Transport in the Juvenile Prawn
}

\author{
Shin-ichi Teshima, ${ }^{* 1}$ Akio Kanazawa, ${ }^{* 1}$ and Yasuo Kakuta*2 \\ (Accepted June 28, 1985)
}

\begin{abstract}
The present investigation was undertaken to see the postprandial variation in lipid compositions of the hepatopancreas, hemolymph, and muscle after feeding of the test diets with $3 \%$ soybean lecithin (diet A) and without supplemental phospholipids (PL) (diet D) to understand the nutritional role of dietary PL in the prawn Penaeus japonicus. Total lipid (TL) concentrations of the hepatopancreas and hemolymph were higher in the prawns receiving diet $A$ than in those receiving diet $\mathrm{D}$ during the holding period from $1 \mathrm{~h}$ to $6 \mathrm{~h}$ after feeding. The increase of TL concentrations of the hepatopancreas was mostly attributable to that of neutral lipids (NL) such as triglycerides (TG) and cholesterol $(\mathrm{CH})$, whereas that of the hemolymph was mainly due to PL such as phosphatidylcholine besides NL such as TG and CH. On the other hand, no remarkable difference was seen about the variation of lipid class concentrations of the muscle between the two diet groups as observed in the hepatopancreas and hemolymph. On the basis of these data, dietary PL was suggested to take some part in the transport of dietary lipids such as cholesterol and triglycerides in the body through the hemolymph.
\end{abstract}

During the course of our continuing studies on the nutritional requirements of the prawn Penaeus japonicus, we have found that the inclusion of dietary phospholipids (PL) in diets was necessary for good growth and high survival of the larval ${ }^{1-3)}$ and juvenile prawns." Kanazawa et al..$^{5)}$ have examined the efficacy of various PL in improving growth and survival rates of the larval $P$. japonicus, and have shown that the requisite for effective PL is to possess choline and inositol groups besides unsaturated fatty acids such as linoleic $(18: 2 \omega 6)$, linolenic (18: $3 \omega 3)$, icosapentaenoic $(20: 5 \omega 3)$, and docosahexaenoic $(22: 6 \omega 3)$ acids as fatty acid moieties. ${ }^{3,5)}$ However, it is not clear why dietary sources of PL enhance growth and survival of the prawn.

Since the mechanism of lipid transport in crustaceans such as the prawn is likely to be different from that in higher animals, ${ }^{\theta-11)}$ the requirements for dietary PL in the prawn may be related to the transport of dietary lipids such as triglycerides (TG) and cholesterol in the body. In the present study, hence, we intend to examine the effects of dietary PL, soybean lecithin, in diets on the assimilation and transport of dietary lipids in the juvenile prawn $P$. japonicus. To this ap- proach, the prawns were fed on the PL-supplemented and PL-deficient diets, and then the variation in lipid compositions of the hepatopancreas, hemolymph, and muscle after feeding of the diets was investigated in relation to the nutritional role of $P L$ in diets.

\section{Materials and Methods}

\section{Prawns and Feeding of Test Diets}

The specimens of the prawn $P$. japonicus were obtained from Mitsui-Nohrin-Kaiyosangyo $\mathrm{Co}$. Ltd., Kagoshima, and maintained on a commercial prawn diet until use. The prawns, weighing an average of $10.0 \mathrm{~g}$ each, were starved for $24 \mathrm{~h}$ prior to the feeding of test diets, divided into 2 groups of 12 prawns each into $30 \mathrm{l}$-aquaria, and then fed on test diets A and D at the $5 \%$ level of their body weight. The compositions of the test diets were the same as those reported previously. ${ }^{12)}$ Diet A contained $3.0 \%$ soybean lecithin (Kanto Chemical Co., Ltd.) besides $6.0 \%$ pollack liver oil (PLO) and $0.5 \%$ cholesterol as lipid sources, whereas diet D contained no supplemental PL. The diet preparation, feeding, and rearing techniques for the prawn were similar to those described previously. ${ }^{12-11)}$

*1 Faculty of Fisheries, University of Kagoshima, 50-20 Shimoarata-4, Kagoshima 890, Japan (手酉新一, 金沢昭夫: 蝔监島大学水学部).

*2 Present address: Asu Seiyaku K.K., 3218-12 Sakoshi, Ako, Hyogo 638-01, Japan (觕田泰男：ア一ス製 薬株式会社). 
Table 1. Variation of lipid class concentrations $(\mu \mathrm{g} / \mathrm{mg}$ tissue) in the hepatopancreas of prawns after feeding of PL-supplemented (diet $\mathrm{A})$ and PL-deficient (diet $\mathrm{D})$ diets

\begin{tabular}{|c|c|c|c|c|c|c|c|}
\hline \multirow{3}{*}{$\begin{array}{c}\text { Lipid } \\
\text { class }\end{array}$} & \multirow{3}{*}{$\begin{array}{c}\text { Before } \\
\text { feeding*2 }\end{array}$} & \multicolumn{6}{|c|}{ Holding period } \\
\hline & & \multicolumn{2}{|c|}{$1 \mathrm{~h}$} & \multicolumn{2}{|c|}{$3 \mathrm{~h}$} & \multicolumn{2}{|c|}{$6 \mathrm{~h}$} \\
\hline & & Diet $A$ & Diet D & Diet A & Diet D & Diet A & Diet D \\
\hline TL & 3,450 & 3,560 & 3,230 & 3,610 & 3,060 & 4,000 & 3,610 \\
\hline PL & 1,330 & 707 & 984 & 1,050 & 904 & 1,460 & 891 \\
\hline NL & 2,120 & 2,853 & 2,246 & 2,560 & 2,156 & 2,540 & 2,717 \\
\hline $\mathrm{HC}$ & 65 & 73 & 43 & 76 & 60 & 89 & 66 \\
\hline $\mathrm{SE}$ & 113 & 88 & 59 & 81 & 44 & 82 & 79 \\
\hline $\mathrm{TG}$ & 1,017 & 1,693 & 1,211 & 1,478 & 1,173 & 1,208 & 1,254 \\
\hline FFA & 578 & 575 & 476 & 487 & 468 & 574 & 519 \\
\hline $\mathrm{DG}$ & 108 & 123 & 161 & 76 & 195 & 184 & 519 \\
\hline FS & 239 & 301 & 296 & 362 & 214 & 403 & 280 \\
\hline MG & 0 & 0 & 0 & 0 & 2 & 0 & 0 \\
\hline $\mathrm{PE}$ & 178 & 182 & 200 & 189 & 238 & 292 & 273 \\
\hline PS & 4 & 5 & 7 & 4 & 22 & 6 & 29 \\
\hline PI & 97 & 45 & 99 & 65 & 62 & 78 & 45 \\
\hline PC & 630 & 280 & 393 & 523 & 351 & 690 & 298 \\
\hline SM & 21 & 10 & 14 & 13 & 13 & 14 & 23 \\
\hline LPC & 290 & 114 & 184 & 129 & 130 & 205 & 116 \\
\hline PA & 8 & 1 & 1 & 4 & 1 & 6 & 2 \\
\hline UK & 102 & 70 & 86 & 123 & 87 & 169 & 107 \\
\hline $\begin{array}{ll}\text { *1 } & \mathrm{TL}, \\
& \mathrm{DG}, \\
& \text { dylin } \\
& \text { phos } \\
\text { *2 } & \text { The }\end{array}$ & $\begin{array}{l}\text { lipid; PL, } \\
\text { yceride; FS, } \\
\text { 1; PC, phos } \\
\text { ipids. } \\
\text { topancreas }\end{array}$ & $\begin{array}{l}\text { holipid; } \\
\text { sterol; } \\
\text { aylcholin } \\
\text { btained f }\end{array}$ & $\begin{array}{l}\text { tral lipid } \\
\text { noglyder } \\
\text { phingom } \\
\text { prawns }\end{array}$ & ocarbor & $\begin{array}{l}\text { ryl ester; } \\
\text { olamine; } \\
\text { lcholine; }\end{array}$ & $\begin{array}{l}\text { yceride; F } \\
\text { phatidylser } \\
\text { sphatidic }\end{array}$ & $\begin{array}{l}\text { ree fatty a } \\
\text { PI, phosph } \\
\text { UK, unkn }\end{array}$ \\
\hline
\end{tabular}

Lipid Analysis of the Hepatopancreas, Hemolymph, and Muscle

In crustaceans such as the prawn, it seems likely that dietary lipids are mainly assimilated at the region of the hepatopancreas (mid-gland), ${ }^{15-17)}$ and the lipids stored in the hepatopancreas are then transported to the extrahepatic organs and tissues such as the muscle through the hemolymph. ${ }^{\text {in }}$ If dietary PL are concerned with the effective assimilation and transport of lipids in diets, a notable difference may be seen between two prawn groups receiving the PL-supplemented and PL-deficient diets about the postprandial variation in lipid compositions of the hepatopancreas and hemolymph. In the present study, therefore, the hepatopancreas, hemolymph, and muscle were dissected out from the prawns 1,3 , and $6 \mathrm{~h}$ after feeding of test diets for lipid analysis. Total lipids (TL) were extracted with chloroform-methanol-water ${ }^{18)}$ and then separated into neutral lipid (NL) and phospholipid (PL) fractions by column chromatography on Kieselgel 60 as described previously. ${ }^{10}$ NL was further separated into lipid classes by thin-layer chromatography (TLC) and quantified by the method of
Amenta. ${ }^{20)}$ Each PL class concentration and the positional distribution of fatty acid moieties of phosphatidylcholine (PC) were determined as mentioned previously. ${ }^{12)}$

\section{Results and Discussion}

First, lipid analysis was conducted with the hepatopancreas, hemolymph, and muscle of the prawns starved for $24 \mathrm{~h}$ prior to the feeding trial. The hepatopancreas of starved prawns contained TG, free fatty acids (FFA), free sterols (FS), phosphatidylethanolamine (PE), and $\mathrm{PC}$ as the major lipid classes (Table 1). In contrast to the hepatopancreas, the hemolymph contained PL comprising $\mathrm{PC}$ and $\mathrm{PE}$ mainly much more than NL. The abundance of PC and PE in the hemolymph suspects the contribution of these PL classes to the dietary lipid transport in the prawn (Table 2). The muscle contained FS and PC as the prominent lipid classes (Table 3) which may be important as the cell components ${ }^{21}$ of muscle. Table 4 shows the positional distribution of fatty acids of PC isolated from the hepatopancreas, hemolymph, and muscle. In every organ and tissue examined, the fatty acid moities at the $\alpha$ - 
Table 2. Variation of lipid class concentrations $(\mu \mathrm{g} / \mathrm{mg}$ wet wt.) in the hemolymph of prawns after feeding of PL-supplemented (diet A) and PL-deficient (diet D) diets

\begin{tabular}{|c|c|c|c|c|c|c|c|}
\hline \multirow{3}{*}{$\begin{array}{l}\text { Lipid } \\
\text { class* }\end{array}$} & \multirow{3}{*}{$\begin{array}{l}\text { Before } \\
\text { feeding }\end{array}$} & \multicolumn{6}{|c|}{ Holding period } \\
\hline & & \multicolumn{2}{|c|}{$1 \mathrm{~h}$} & \multicolumn{2}{|c|}{$3 \mathrm{~h}$} & \multicolumn{2}{|c|}{$6 \mathrm{~h}$} \\
\hline & & Diet A & Diet D & Diet A & Diet D & Deit A & Diet D \\
\hline$T L$ & 242.8 & 225.8 & 209.3 & 233.5 & 191.8 & 267.7 & 178.4 \\
\hline PL & 140.7 & 117.5 & 104.7 & 121.2 & 92.5 & 138.7 & 88.3 \\
\hline NL & 102.1 & 108.3 & 104.6 & 112.3 & 99.3 & 129.0 & 90.1 \\
\hline $\mathrm{HC}$ & 6.6 & 4.5 & 9.7 & 5.3 & 6.1 & 5.0 & 5.5 \\
\hline SE & 6.7 & 4.2 & 6.7 & 4.4 & 5.1 & 5.1 & 4.3 \\
\hline TG & 13.5 & 16.4 & 14.7 & 22.0 & 22.4 & 22.4 & 18.1 \\
\hline FFA & 35.1 & 30.2 & 29.5 & 29.1 & 23.6 & 33.1 & 28.9 \\
\hline $\mathrm{DG}$ & 11.3 & 19.2 & 14.5 & 17.7 & 16.3 & 20.0 & 9.5 \\
\hline FS & 28.9 & 33.8 & 29.5 & 33.8 & 25.8 & 43.4 & 23.8 \\
\hline $\mathrm{MG}$ & 0 & 0 & 0 & 0 & 0 & 0 & 0 \\
\hline PE & 44.5 & 33.2 & 22.9 & 37.3 & 30.5 & 29.7 & 31.9 \\
\hline PS & 0.4 & 0.9 & 1.0 & 1.1 & 0.9 & 0.6 & 1.5 \\
\hline PI & 4.0 & 3.5 & 3.8 & 2.5 & 1.1 & 4.0 & 0.9 \\
\hline PC & 51.8 & 45.7 & 45.1 & 43.3 & 31.8 & 55.4 & 30.9 \\
\hline SM & 0.4 & 0.3 & 1.2 & 1.0 & 1.6 & 0.5 & 1.5 \\
\hline LPC & 13.6 & 12.2 & 11.1 & 14.1 & 10.3 & 22.0 & 8.9 \\
\hline PA & 0.2 & 0.1 & 0.2 & 0.2 & 0.2 & 0.3 & 0.1 \\
\hline UK & 25.8 & 21.6 & 19.2 & 21.7 & . 16.1 & 26.2 & 12.6 \\
\hline
\end{tabular}

* See Table 1 for the abbreviations used.

Table 3. Variation of lipid class concentrations $(\mu \mathrm{g} / \mathrm{mg}$ tissue) in the muscle of prawns after feeding of PL-supplemented (diet A) and PL-deficient (diet D) diets

\begin{tabular}{|c|c|c|c|c|c|c|c|}
\hline \multirow{3}{*}{$\begin{array}{l}\text { Lipid } \\
\text { class* }\end{array}$} & \multirow{3}{*}{$\begin{array}{l}\text { Before } \\
\text { feeding }\end{array}$} & \multicolumn{6}{|c|}{ Holding period } \\
\hline & & \multicolumn{2}{|c|}{$1 \mathrm{~h}$} & \multicolumn{2}{|c|}{$3 \mathrm{~h}$} & \multicolumn{2}{|c|}{$6 \mathrm{~h}$} \\
\hline & & Deit A & Diet D & Diet A & Diet $D$ & Diet A & Diet D \\
\hline TL & 1,077 & 1,112 & 1,027 & 1,202 & 1,006 & 1,292 & 1,263 \\
\hline PL & 538 & 533 & 504 & 535 & 446 & 618 & 504 \\
\hline NL & 539 & 579 & 523 & 667 & 560 & 674 & 759 \\
\hline $\mathrm{HC}$ & 19 & 20 & 17 & 37 & 24 & 34 & 29 \\
\hline $\mathrm{SE}$ & 21 & 23 & 19 & 35 & 20 & 33 & 32 \\
\hline $\mathrm{TG}$ & 58 & 98 & 103 & 116 & 88 & 75 & 122 \\
\hline FFA & 139 & 117 & 106 & 144 & 112 & 155 & 170 \\
\hline $\mathrm{DG}$ & 61 & 70 & 65 & 57 & 88 & 75 & 101 \\
\hline FS & 226 & 250 & 211 & 278 & 228 & 302 & 303 \\
\hline MG & 15 & 1 & 2 & 0 & 0 & 0 & 2 \\
\hline $\mathrm{PE}$ & 146 & 114 & 118 & 131 & 131 & 187 & 140 \\
\hline PS & 3 & 2 & 3 & 3 & 7 & 5 & 19 \\
\hline PI & 62 & 46 & 63 & 57 & 37 & 66 & 33 \\
\hline PC & 222 & 260 & 208 & 217 & 168 & 218 & 189 \\
\hline SM & 6 & 7 & 6 & 10 & 6 & 8 & 7 \\
\hline LPC & 14 & 44 & 33 & 29 & 25 & 35 & 40 \\
\hline PA & 1 & 3 & 1 & 1 & 1 & 1 & 1 \\
\hline UK & 84 & 57 & 72 & 87 & 71 & 99 & 75 \\
\hline
\end{tabular}

- See Table 1 for the abbreviations used.

and $\beta$-positions were mainly composed of the saturated fatty acids such as 16:0 and 18:0 and the unsaturated fatty acids such as 18:169, 20:
$5 \omega 3$, and $22: 6 \omega 3$, respectively.

Next, the feeding experiments were carried out to manifest the time-course changes in lipid composi- 
Table 4. Positional distribution of fatty acids of phosphatidylcholine (PC) from the hepatopancreas, hemolymph, and muscle of the prawn juveniles starved for $24 \mathrm{~h}$.

\begin{tabular}{|c|c|c|c|c|c|c|c|c|c|}
\hline \multirow{3}{*}{ Fatty acid } & \multicolumn{9}{|c|}{ Fatty acid composition $(\%)$} \\
\hline & \multicolumn{3}{|c|}{ Hepatopancreas } & \multicolumn{3}{|c|}{ Hemolymph } & \multicolumn{3}{|c|}{ Muscle } \\
\hline & Total & $\alpha$-Pos. & $\beta$-Pos. & Total & $\alpha$-Pos & $\beta$-Pos. & Total & $\alpha$-Pos. & $\beta$-Pos. \\
\hline $12: 0$ & 5.9 & 8.0 & $t^{*}$ & 3.4 & 4.5 & $t$ & 4.2 & 9.4 & 0 \\
\hline $14: 0$ & 5.8 & 11.4 & 1.4 & 2.2 & 6.7 & $\mathrm{t}$ & 6.3 & 11.8 & 2.6 \\
\hline $16: 0$ & 15.4 & 47.4 & 4.5 & 20.3 & 57.7 & 4.3 & 14.1 & 43.4 & 3.1 \\
\hline $16: 1 \omega 7$ & 2.6 & 1.5 & 0.9 & 1.7 & $\mathrm{t}$ & 0 & 8.4 & 3.3 & 10.4 \\
\hline $16: 3 \omega 3$ & 1.2 & $t$ & 1.0 & $\mathrm{t}$ & $t$ & 0 & $t$ & 0 & 0 \\
\hline $18: 0$ & 8.9 & 18.0 & 1.2 & 9.9 & 20.4 & 2.0 & 13.4 & 24.6 & 3.0 \\
\hline $18: 109$ & 10.2 & 1.2 & 11.0 & 9.5 & 1.4 & 11.1 & 7.5 & 2.2 & 8.0 \\
\hline $18: 2 \omega 6$ & 2.6 & 1.4 & 3.9 & 2.3 & 0 & 2.0 & 2.7 & 1.1 & 2.5 \\
\hline $18: 3 \omega 3$ & 0 & 0 & 0 & $t$ & 0 & $\mathrm{t}$ & 0 & 0 & 0 \\
\hline $20: 1 \omega 9$ & 2.3 & 0 & t & 2.2 & 0.8 & 1.2 & 2.7 & 0 & 0 \\
\hline $20: 2 \omega 6$ & 3.4 & 3.5 & $\mathrm{t}$ & 3.4 & 3.5 & $\mathrm{t}$ & 0 & 0 & 0 \\
\hline $20: 5 \omega 3$ & 11.1 & 3.5 & 28.6 & 15.7 & 3.2 & 29.8 & 14.8 & 1.2 & 28.1 \\
\hline $20: 4 \omega 6$ & 1.8 & 1.1 & 2.1 & 0.9 & 0.6 & 0.9 & 1.3 & 0 & 1.5 \\
\hline $22: 1 \omega 9$ & 1.5 & 0.9 & 2.1 & 0.7 & 0 & 1.0 & 1.2 & 0.8 & 0.9 \\
\hline $22: 5 \omega 3$ & 0.7 & 0 & 1.8 & 0.6 & 0 & 3.9 & 2.6 & 0.7 & 0.7 \\
\hline $22: 6 \omega 3$ & 26.4 & 4.3 & 41.7 & 28.5 & 3.9 & 43.0 & 20.8 & 1.5 & 35.8 \\
\hline Saturates & 36.1 & 84.8 & 7.1 & 35.7 & 89.2 & 8.7 & 38.0 & 89.2 & 8.7 \\
\hline Unsaturates & 63.9 & 15.2 & 92.9 & 64.3 & 10.8 & 91.3 & 62.0 & 10.8 & 91.3 \\
\hline (13-Series & 39.7 & 7.8 & 73.1 & 44.7 & 7.1 & 76.7 & 38.3 & 2.7 & 64.7 \\
\hline
\end{tabular}

* Less than $0.5 \%$.

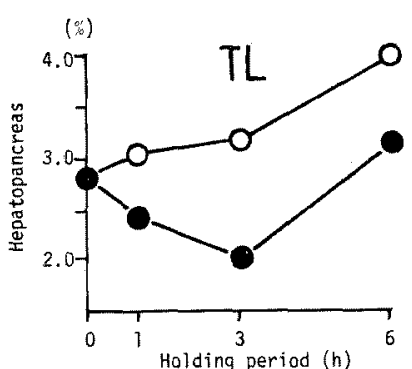

$(\%)$

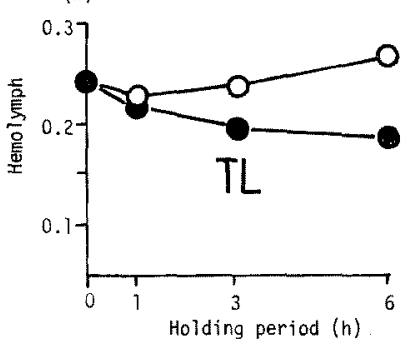

(\%)
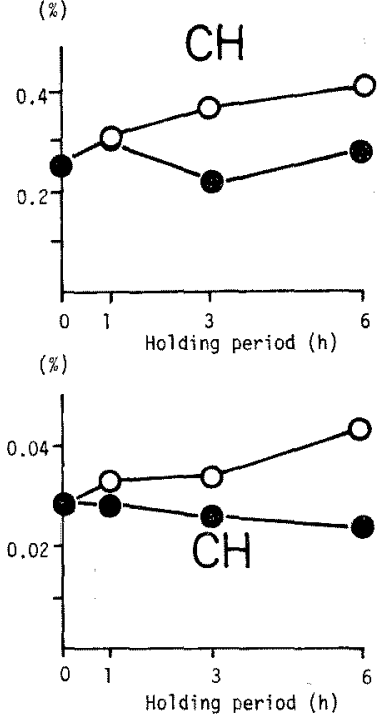
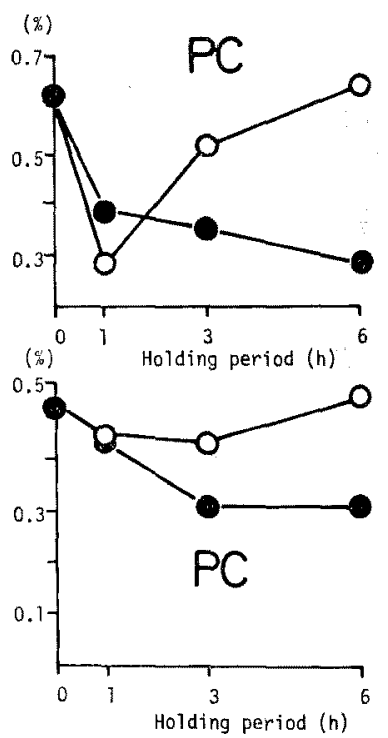

Fig. 1. Variation of total lipid (TL), cholesterol $(\mathrm{CH})$, and phosphatidylcholine (PC) concentrations (\% of fresh matter) in the hepatopancreas and hemolymph of the prawns after feeding of the test diets.

O, diet A (PL-supplemented); $\mathbf{0}, \operatorname{diet} \mathrm{D}$ (PL-deficient)

tions of the hepatopancreas, hemolymph, and muscle after feeding of the diets containing PLO and cholesterol as lipid sources. Table 1,2 and 3 show the postprandial variation in the lipid class concentrations of the hepatopancreas, hemolymph, and muscle, respectively. Through- 
out the holding period, TL concentrations of the hepatopancreas, expressed as $\mu \mathrm{g} / \mathrm{mg}$ fresh wt., were higher in the prawns receiving the PL-supplemented diet (diet $A$ ) than in those receiving the PL-deficient diet (diet D). This suggests that dietary PL such as soybean lecithin accelerate the mobilization of dietary lipids from the guts to the hepatopancreas. In the prawns receiving $\operatorname{diet} \mathrm{A}$, the hepatopancreatic TL concentrations was increased $1 \mathrm{~h}$ after feeding of the diet mainly due to the elevation of NL such as TG. But, the subsequent increase of hepatopancreatic TL during the period of $1 \mathrm{~h}$ to $6 \mathrm{~h}$ after feeding was mainly attributable to that of $\mathrm{PC}$ and $\mathrm{PE}$, suggesting the conversion of dietary $T G$ to these PL classes in the hepatopancreas. It was also noteworthy that free sterol concentrations of the hepatopancreas were markedly increased from an initial level of $239 \mu \mathrm{g} / \mathrm{mg}$ to $403 \mu \mathrm{g} / \mathrm{mg}$ after $6 \mathrm{~h}$ when the prawns fed diet $\mathrm{A}$ with supplemental soybean lecithin.

The hemolymph TL and PL concentrations were also higher in the prawns receiving diet $\mathbf{A}$ than in those receiving diet $D$ throughout the holding period. A marked increase of the hemolymph PL during the period of $1 \mathrm{~h}$ to $6 \mathrm{~h}$ after feeding was mainly due to the elevation of $\mathrm{PC}$ (Fig. 1) which might be released from the hepatopancreas. ${ }^{7)}$ Interestingly, the hemolymph FS concentrations increased notably with the lapse of holding time when the prawn fed the PL-supplemented diet as also observed in the hepatopancreas. Previously, we have shown that lipid transport in the prawn through the hemolymph was likely to be operated as a form of PL. ${ }^{\theta-11)}$ The presence of PC containing 20:5 203 and $22: 6 \omega 3$ at the $\beta$-position in the hemolymph (Table 4) may suggest the importance of this lipid class in lipid transport. The feeding experiments on the larval prawn $P$. japonicus have also shown that the PC containing unsaturated fatty acids was most effective in improving growth and survival rates. ${ }^{3)}$ On the other hand, no remarkable difference was seen about the variation of lipid class concentrations of the muscle between the two diet groups as observed in the hepatopancreas and hemolymph.

These considerations lead to the conclusion that dietary PL, soybean lecithin, possibly accelerate the mobilization of dietary $\mathrm{TG}$ and cholesterol from the guts and hepatopancreas to the hemolymph. The deficient of PL in diets may result in the ineffective utilization of dietary lipids due to the above reason.

\section{References}

1) A. Kanazawa: in "Proceedings of 2nd International Conference on Aquaculture Nutrition" (ed. by G. D. Pruder, C. J. Langdon, and D. E. Conklin), Special Publication No. 2, World Mariculture Society, Louisiana State University, Baton Rouge, 1982, pp. 87-105.

2) S. Teshima, A. Kanazawa, H. Sasada, and M. Kawasaki: Mem. Fac. Fish. Kagoshima Univ., 31, 193-199 (1982).

3) S. Teshima: in "Fish Nutrition and Diets" (ed. by Y. Yone), Suisangaku Series No. 54, Koseishakoseikaku, Tokyo, 1985, pp. 20-30.

4) A. Kanazawa, S. Teshima, S. Tokiwa, M. Endo, and F. A. Abdel Razek: Bull. Japan. Soc. Sci. Fish., 45, 961-965 (1979).

5) A. Kanazawa, S. Teshima, and M. Sakamoto: Aquaculture, 50, 39-49 (1985).

6) S. Teshima and A. Kanazawa: Bull. Japan. Soc. Sci. Fish., 44, 925 (1978).

7) S. Teshima and A. Kanazawa: Bull. Japart. Soc. Sci. Fish., 44, 1269-1274 (1978).

8) S. Teshima and A. Kanazawa: Bull. Japan. Soc. Sci. Fish., 45, 1341-1346 (1979).

9) S. Teshima and A. Kanazawa: Bull. Japan. Soc. Sci. Fish., 46, 51-55 (1980).

10) S. Teshima and A. Kanazawa: Bull. Japan. Soc. Sci. Fish., 46, 57-62 (1980).

11) S. Teshima and A. Kanazawa: Min. Rev. Data File Fish. Res., Kagoshima Univ., 1, 1-25 (1980).

12) S. Teshima, A. Kanazawa, and Y. Kakuta: Bull. Japan. Soc. Sci. Fish., 52, 155-158, (1986).

13) A. Kanazawa, M. Shimaya, M. Kawasaki, and K. Kashiwada: Bull. Japan. Soc. Sci. Fish., 36, 949-954 (1970).

14) A. Kanazawa, S. Teshima, and S. Tokiwa: Bull. Japan. Soc. Sci. Fish., 43, 849-856 (1977).

15) H. J. Vonk: in "The Physiology of Crustaceans" (ed. by T. H. Waterman), Vol. 1, Academic Press, New York, 1960, pp. 291-316.

16) T. Nose: Bull. Freshwater Fish. Res. Lab., 14, 23-28 (1964).

17) O. Deshimaru: Bull. Japan. Soc. Sci. Fish., 42, 331-335 (1976).

18) E. G. Bligh and W. J. Dyer: Can. J. Biochem. Physiol., 37, 911-917 (1959).

19) S. Teshima and A. Kanazawa: Bull. Japan. Soc. Sci. Fish., 42, 1129-1135 (1976).

20) J. S. Amenta: J. Lipid Res., 5, 270-272 (1964).

21) D.G. Bishop: in "Biochemistry and Methodology of Lipids" (ed. by A. R. Johnson and J. B. Davenport), Wiley-Interscience, New York, London, Sydney, and Toronto, 1971, pp. 425458. 